\title{
Cyborgs as Front-line Service Employees: A Research Agenda
}

\begin{tabular}{|r|l|}
\hline Journal: & Journal of Service Theory and Practice \\
\hline Manuscript ID & JSTP-11-2018-0241.R5 \\
\hline Manuscript Type: & Research Paper \\
\hline Keywords: & $\begin{array}{l}\text { Cyborgs, Service and Service Delivery, Emergent Technologies, Front } \\
\text { Line Service Employees }\end{array}$ \\
\hline \multicolumn{2}{|l}{} \\
\hline
\end{tabular}

\section{SCHOLARONE \\ Manuscripts}




\section{Cyborgs as Front-line Service Employees: A Research Agenda}

\section{Abstract}

\section{Purpose}

This paper identifies and explores potential applications of cyborgian technologies within service contexts and how service providers may leverage the integration of cyborgian service actors into their service proposition. In doing so, the paper proposes a new category of 'melded' frontline service employees (FLEs), where advanced technologies become embodied within human actors. The paper presents potential opportunities and challenges that may arise through cyborg technological advancements and proposes a future research agenda related to these.

\section{Design/methodology}

This study draws on literature in the fields of services management, Artificial Intelligence [AI], robotics, Intelligence Augmentation [IA] and Human Intelligence [HIs] to conceptualise potential cyborgian applications.

\section{Findings}

The paper examines how cyborg bio- and psychophysical characteristics may significantly differentiate the nature of service interactions from traditional 'unenhanced' service interactions. In doing so, we propose 'melding' as a conceptual category of technological impact on FLEs. This category reflects the embodiment of emergent technologies not previously captured within existing literature on cyborgs. We examine how traditional roles of FLEs will be potentially impacted by the integration of emergent cyborg technologies, such as neural interfaces and implants, into service contexts before outlining future research directions related to these, specifically highlighting the range of ethical considerations.

\section{Originality/Value}

Service interactions with cyborg FLEs represent a new context for examining the potential impact of cyborgs. This paper explores how technological advancements will alter the individual capacities of humans to enable such employees to intuitively and empathetically create solutions to complex service challenges. In doing so, we augment the extant literature on cyborgs, such as the body hacking movement. The paper also outlines a research agenda to address the potential consequences of cyborgian integration.

\section{Key Words}

Cyborgs, Service and Service Delivery, Emergent Technologies, Front Line Service Employees

\section{Article Classification \\ Conceptual}




\section{Introduction}

Evolving technologies are rapidly transforming the nature of services, service customer experiences and the very essence of relationships between customers and service providers (van Doorn, et al., 2017). In terms of applications, there has been much focus on the 'infusion' of smart technologies, Artificial Intelligence (AI) (Huang and Rust, 2018) and/or the assimilation of robots into service delivery processes (e.g., De Keyser, et al., 2019; Wirtz et al., 2018; Galeon and Reedy, 2017). However, the nature of emergent technologies and their application within service delivery systems is increasingly blurring the boundaries between 'physical, digital and biological spheres' (Huang and Rust, 2018: 155). Drawing on and augmenting the robotics and AI literatures, researchers within marketing (e.g., Belk, 2016; 2017; 2018; Galeon and Reedy, 2017) are predicting the rapid convergence of AI-based systems (robots) and intelligent augmentation (IA) systems (e.g., insideables and neuroprosthetics) with humans (biological systems) within the next 10-30 years. Related to this, an important but neglected entity in the evolution of service delivery is the role of robothuman hybrids, otherwise known as cyborgs. A cyborg may be defined as a modified (augmented) human (Haraway, 1985; Buchanan-Oliver, et al., 2010) that integrates technologies within the body by way of mechanical and/or technological 'insideables'. A recent report by the Royal Society (2019) highlights the urgency with which issues related to the adoption and use of such technologies by business should be considered, stating "the opportunities are unprecedented and immense - as are the challenges". Such interfaces offer unimaginable benefits but also pose risks, such as privacy and human rights issues, and social inequality. There is currently no established infrastructure for their adoption in business, such as a legislative framework, ethical context or industrial best practice in their adoption and use.

This paper aims to explore the potential role of cyborgs within service contexts and to further develop existing classifications and the roles of both technology and frontline employees (FLEs) so as they encompass the impacts of cyborgs within service contexts. To achieve this, we briefly examine extant literature on FLEs and their roles (e.g., Bowen, 2016). Drawing on the work of Larivière, et al. (2017), we propose an additional classification that reflects the fusion of emergent technology and humans. We subsequently examine how traditional roles of FLEs will be impacted by the integration of cyborgs into service contexts before outlining future research directions related to these. In doing so, the paper highlights the need for further research in relation to service contexts and considers the directions in which this might expand in future. 


\section{FLEs and Service Delivery}

The imperative to create value and enable value exchange manifests itself in the dynamic relationship between FLEs and customers (Subramony and Pugh, 2015; Gabriel, et al., 2016; Groth, et al., 2019). There is a plethora of research that demonstrates empirical links between employee satisfaction and productivity, service value, customer satisfaction and loyalty, and the revenue growth and profitability of the firm associated with these (Heskett, et al., 1997; Anderson, et al., 2004; Wirtz and Jerger, 2017). The role of FLEs as stewards of customer contact and relationship management has long been recognised within such research (e.g., Schlesinger and Heskett, 1991) to the extent that the very nature and outcome of service encounters are significantly shaped by their characteristics (e.g., Bitner 1990; Berry, 1995; Grönroos, 1984; Rust and Oliver, 1994; Homburg and Stock, 2004). In examining FLEs, Singh et al. (2017) define the organisational frontline as 'the study of interactions and interfaces at the point of contact between an organisation and its customers that promotes, facilitates, or enables value creation and value exchange' (Singh, et al., 2017:4). However, value is a subjective judgment and based on intangible interpersonal interactions between FLEs and customers. As such, these 'moments of truth' (Bitner, 1990) are based on the subjective perceptions of both FLEs and customers. Hence, understanding and management of these interactions and interfaces, or 'touch points', is critical to organisational success. CustomerFLE interactions may be characterised by complexity, co-production, co-creation, productivity, efficiency, efficacy and problem solving and are increasingly enabled by complex service systems that encompass actors, technologies and resources (e.g., Schneider and Bowen, 2019; De Keyser, et al., 2019). Similarly, interfaces are characterised by the extent of automation, flexibility, synchronicity/specificity, openness, complexity and the very nature of the servicescape. In attempting to comprehend and structuralise interaction and interface characteristics, Bowen (2016) identifies four key roles of FLEs within contemporary service contexts: differentiator, enabler, coordinator and innovator.

\section{The Role of Differentiator}

FLEs are instrumental in adapting service to suit individual needs thereby enhancing customer experience (Lai, et al., 2014; Motamarri, et al., 2017). However, cost reduction to achieve process efficiencies increasingly moves many service firms towards a commoditised model of service provision with associated consequences for customer experience. Within such environments, 'small details' can have a significant impact (Bolton, et al., 2014): identifying 
and evaluating touch points such as emotional engagement and authenticity through intimacy and passion have been demonstrated to enhance customer loyalty (Yim, et al., 2008). A nonsubstitutable personal touch can mitigate customer perceived commoditization (Motamarri, et al., 2017).

In relation to this, services research has long recognised the ways in which human service providers may be perceived as demonstrating emotion, empathy and understanding and hence the potential to evoke positive affect and user feelings of attachment (e.g., Sierra and McQuitty, 2005). Empathetic intelligence is the ability to recognize, understand and influence other peoples' emotions (Goleman, 1996) and to learn and adapt emphatically based on experience. Drawing on previous research in this area (e.g., Gardner 1983; Johnson 2014), Huang and Rust (2018) identify empathetic intelligence as encompassing interpersonal, social and people skills that help humans to be sensitive to others' feelings, albeit some have highlighted this as potential exploitation of employee emotions (see e.g., Grandey, Fisk and Steiner, 2005; Hartley, 2018). The ability of FLEs to 'infect' and sense emotions (Pugh, 2001; Hennig-Thurau, et al., 2006) has been shown to have a significant role in perceptions of service quality and, ultimately, customer satisfaction (Hunt, 1993). As such, service organisations frequently require FLEs to display positive emotions during service encounters and/or to suppress negative emotions (Groth, et al., 2019). FLEs' observable emotional displays such as facial expressions, gestures and tone of voice, are required to be authentic displays of emotions and adhere to those expected. The skillset associated with empathetic emotions typically includes negotiating, advocating, leadership, relationship building and communication (Caprino, 2012).

\section{The Role of Enabler}

The customer's role as co-producer of a service has expanded (e.g., De Keyser, et al., 2019). As such, FLEs are increasingly responsible for assessing customers as 'human resources' (Bowen, 2016) whose skills and competencies are leveraged to optimise service experience. This may entail 'socialising and training' customers about their role in the co-production process (Guo, et al., 2013). The heterogeneous nature of customers in terms of their savviness (Macdonald and Uncles, 2007) and sophistication (Garry and Harwood, 2009) will determine the nature and extent of enabling necessary. Such roles frequently require not only technical competencies but also interpersonal skills (Larivière, 2014) that require varying degrees of 'rapport-building behaviour' with customers (Geibelhausen et al., 2014; Bowen, 2016). 


\section{The Role of Coordinator}

As early as the 1980s, Lovelock (1981) identified service employees acting as a 'service trinity' that encompassed helping to run service operations, marketing the service and being the visible customer-facing facet of the firm. Subsequently, Zeithaml, et al. (1985) define FLEs as 'those at the boundary of a firm, interacting with customers on behalf of and representing the firm'. This unique position in the organisation places FLEs as 'boundary spanners' (Wirtz and Jerger, 2016). FLEs are the interface between the inside and outside of the firm, operating at the boundary of the organisation communicating both the voice of the firm externally and the voice of the customer internally (Bettencourt, et al., 2005). FLEs are also key components of service delivery, informing customer needs and requirements internally to different parts of the organisation (Wirtz and Jerger, 2016).

\section{The Role of Innovator}

Interactions with customers help identify and generate service improvement processes through FLEs' ability to read customers' needs (Lagas and Piercy, 2012). Therefore, the ability to identify customer needs for innovative and creative idea generation of service process improvements and as part of the value creation process for customers becomes an integral role of many FLE positions.

\section{FLEs and service technologies}

Advances in technologies are profoundly disrupting interactions between FLEs and customers, particularly in ways that create and exchange value (Huang and Rust, 2018). These technologies render new types of services to end users together with a range of accompanying interactions that are increasingly complex and diverse in their nature. Whilst some of these, such as the Internet of Things (IoT), are both ubiquitously and inconspicuously consumed within their environment (e.g., Harwood and Garry, 2017), others are made visible through more innovative interfaces and touchpoints (e.g., van Doorn, et al., 2017; Belk, 2016).

In examining the impact of emerging technologies on service encounters, Larivière, et al. (2017) posit that firms infuse technologies into service encounters through adoption in one of three categories: substitution, augmentation and network facilitation. To fully comprehend how cyborgs will warrant their own category, it is necessary to examine these existing categories in more detail. 


\section{Substitution}

Within certain service contexts, advances in smart devices, automation, robotics, sensor fusion and learning algorithms are replacing FLEs. This is particularly the case within services where mechanical intelligence dominates. Mechanical intelligence refers to the ability to perform routine and repeated tasks: with the repetitive nature of such tasks, mechanical intelligence has a relative advantage over humans insofar as these tasks can be done more rapidly, accurately and efficiently without the onset of fatigue or boredom (Marinova, et al., 2017). This reflects evolving managerial focus on developing lean and efficient interfaces with an emphasis on cost saving (Singh, et al., 2017). Current prototype applications of robotic technologies already encompass waiters in restaurants, caregivers for the elderly and hotel concierges. From a service perspective, mechanical intelligence may be optimised where problem solving is relatively simple (Singh, et al., 2017) and the extent of human social presence necessary to perform the task is low (van Doorn, et al., 2017). Mechanical intelligence within such contexts is likely to manifest itself in what Dabholkar (1996) refers to as technology-based self-service tools. These will include interactive voice responses (chatbots), often based within machineto-machine (M2M) contexts, and encompass robotic and automated systems.

Service robots that are autonomous devices have been imbued with machine learning (ML) and $\mathrm{AI}$ and have the ability to process natural language. Whilst the potential and reality of industrial robots to replace humans within manufacturing contexts is being realised, such replacement is increasingly occurring within a more diverse range of contexts including progressively more complex service provision (e.g., Ford, 2017). These technologies render new types of service experience for customers through changing the nature of both interaction and interface with organisations (Wirtz, et al., 2018). For example, remote caregivers give advice to assisted persons through a mobilized robot called ROBIN (Cortellessa, et al., 2018); dancing robots provide support for rehabilitating patients with Parkinson's disease (Chen, et al., 2015) and EVA provides photography at events to engage with clients and attendees (see servicerobots.com). Hence, within some service contexts, an embodied humanoid presence through some form of service robot is already provided (van Doorn, et al., 2017; Wirtz, et al., 2018).

\section{Augmentation}

Larivière, et al. (2017) identify how certain technologies will assist and complement FLEs in the service encounter (Marinova, et al., 2017), where neural interfaces will enable brain signals 
and ultimately thoughts to be detectable through a range of technologies such as vestibular and retinal implants (e.g., Royal Society, 2019). Referred to as Intelligent Augmentation (IA) (Larivière, et al., 2017), technology is used to support human thinking, analysis and behaviour. Analytical intelligence encompasses the ability to process information for problem-solving and to learn from it (Sternberg, 2005), constituting various forms of knowledge management. Analytical intelligence maybe used for performing 'complex, systematic consistent and predictable' tasks (Huang and Rust, 2018). Such problem-solving involves expertise and judgment that draws on tacit knowledge and frequently requires a deviation from service scripts to generate innovative solutions (e.g., Coelho and Augusto, 2010; Kiffin-Peterson, et al., 2012). Individual experiences are effectively and efficiently transformed into experiential knowledge. Related to this, intuitive intelligence is the ability to learn and adapt intuitively by drawing on a range of higher-level skills and cognitions to understand and diagnose a challenge, and identify solutions to address and learn from it (Huang and Rust, 2018). Intuition is generally distinguished as a process of management cognition incorporating intuitive insight and intuitive judgment (Argyris and Schon, 1978; Davenport and Prusak, 2000) and based on levels of expertise and familiarity with problem domains such as medicine and law (e.g., Dorfler and Ackermann, 2012).

Experiential knowledge is converted into processed data through machine learning algorithms responding to, and anticipating the demands of, individual customers (Jayanti and Singh, 2010). Such technologies complement human interaction and enhance problem-solving efficiencies. Indeed, van Doorn, et al. (2017) identify a scenario where a customer co-produces a service with both a human employee and an automated agent. As such, higher levels of applications of knowledge are targets for emergent machine learning algorithms. For example, IBM's Watson supercomputer is in training to support diagnoses of a range of human medical conditions (see Muller, 2018) and complex data visualisations are increasingly using virtual and augmented reality technologies such as head-mounted computers (e.g., Magic Leap, Hololens, Oculus Rift) to support decision-making processes of agents.

\section{Network Facilitation}

Larivière, et al. (2017) identify a third role of technology as that of network facilitation. Network facilitation encompasses the enabling of connections and relationships of multiple actors (machine and human) in service encounters. Analytical intelligence increasingly relies on a move away from standalone technologies to networked technologies that are capable of 
processing massive amounts of data. Smart technologies capable of real-time processing are increasingly being used.

\section{Cyborgs: Technology Melding with FLEs}

Cyborg technology has increasingly received attention in technology, science and medical research fields (see Table 1). Whereas humans have had integrated technologies as a form of medical cybernetic augmentation for a number of years (see for example Adams, 2017; Royal Society, 2019), contemporary applications involve human bio-enhancements, prosthetics and implanted medical devices such as limbs, pacemakers and restorative devices for eyesight, hearing, etc. (Sparrow, et al., 2011). High profile cases include filmmaker Rob Spence's 'eyeborg', a video camera implanted into his eye socket that enables him to capture a firstperson perspective of a scene. Another case is Neil Harbisson, whose 'antenna' (which has been surgically affixed to his brain) enables him to detect ultraviolent and infrared light and replaces his lost sense of colour spectrum with an altered sensory perspective (Adams, 2017). More recently the capability of operating mechanical devices through thoughts has enabled the connecting of individuals' brains with mechanical devices (Winkler, 2017). Extrapolating these developments further, however, suggests such devices will not simply replace or correct psychophysiological functions like-for-like, but increasingly enhance capability. For example, a limb that responds more quickly than a natural limb increasing ambulatory speed or offering extended function; eyesight that provides augmented content direct to the brain; a brain deficiency treatment that enhances cognitive function to a supra-natural level (see e.g., Warwick, 2003; Herr, 2014; Tzafestas, 2018). Researchers have recently demonstrated the feasibility of brain-computer interfaces with accompanying predictions that this may be a precursor to embodying AI networks and notions of 'collective intelligence' being posited (Royal Society, 2019; Huang and Rust 2018; Ascott, 2013).

Larivière, et al. (2017) draw a clear distinction between technology per se and FLEs as humans. Technology may be used to substitute or augment FLE roles. However, we propose a fourth category to Lariviere et al.'s whereby technology is 'melded' with humans to form cyborgs. We see this as distinct from Larivière, et al.'s (2017) augmentation category described above which primarily reflects an externalized use of technologies as tools that augment human action. Instead, we suggest melding reflects a growing movement towards the 'embodied' use of technologies that fundamentally alters human capabilities at both the psychophysical and biological levels. Melding draws on the concept of 'cyborg', where extant literature in business 
and services, defines cyborg as an overarching term that describes a modified human (Haraway, 1985; Buchanan-Oliver, et al., 2010), reflecting a transhumanist ideal of 'self-transformation' and 'self-overcoming' (More, 2010) in which technologies become alterations of the self in ways that enhance and improve performance (e.g., Blackford, 2013) and encompasses 'everyday technologies' such as eyeglasses, etc.

\section{[Insert Table 1 about here]}

Such alterations encompass the integration of technologies within the body by way of mechanical and/or technological implants or 'insideables'. This term was coined by Mouthuy and Carr (2017) as a comparator to the commonly-used term 'wearables'. In the near future, it is likely that enhanced psychophysiological capability through melding with technologies such as neuroprosthetics (see Table 1) will ultimately result in higher levels of productivity, together with lowered levels of personal stress and increased health and longevity (e.g., Blackford, 2013). However, technological advancements are difficult to predict, frequently involve compromise and trade-off and have disadvantages as well as advantages (e.g., Ihde, 2008). Evolutionary ethicists remain highly critical of such technological melding (or medling) (e.g., Peters, 2008; Dupuy, 2011). Nonetheless, advancements are plausible and likely to lead to a number of potential cyborg FLE applications within service industries (e.g., Lovelock, 2019, discusses the 'Nanocene' - a posthuman world in which cyborgs are hyperintelligent electronic beings). In examining these, we initially explore how melding of technology and human may manifest itself before specifically examining how cyborgs may impact service roles.

\section{Cyborgs as FLEs}

Within FLE service contexts, such applications not only relate to manual work where metabolic strength and endurance is required, but also intelligence-based tasks where neuroplasticity, say, for data processing capability is beneficial. However, it is particularly emotionally-based tasks, where increased emotional intelligence is significant that we envisage cyborgian technology will be particularly impactful. In examining this, we once again draw on the notion of Bowen's (2016) 'transformed roles' as a basis for discussion with Table 2 summarising the potential transformation of FLE roles by Cyborgs.

[Insert Table 2 about here] 


\section{Cyborg as Differentiator}

Huang and Rust (2018) propose a division between AI and intuitive and emphatic workers where by analytical AI does the 'heavy-duty' data and information processing in terms of preparation, calculation and analysis. Consequently, FLEs are left to make and communicate 'wise decisions' based on intuitive and emphatic intelligence. Related to this, Marinova et al. (2017) discuss the role of collaborative robots working alongside FLEs and leveraging smart technologies to co-create value with customers. However, with enhanced capability that effectively and efficiently processes big data, melded with human centred intuitive and emphatic intelligence, cyborgs will have 'rapid, on-the-spot access to processed, readily available, accurate, customer specific insights derived from the customer's evolving behaviours and experiences' (Marinova, et al., 2017:33). It is this integration of 'big' and 'small' data coupled with intuitive and emphatic intelligence that offers the potential for significant advantages in the marketplace (Lam, et al., 2017).

With organisations such as IBM estimating global production of data to be 2.3 trillion gigabytes each day and that the world will have created 40 zettabytes of data by 2020 ( $2^{70}$ bytes) (Lam, et al., 2017), the volume of data globally available continues to increase exponentially. Availability of such data refers to what McAfee and Brynjolfsson (2012) refer to as the $3 \mathrm{~V}$ components of big data: volume (the amount of data), velocity (the speed of data) and variety (sources of data). However, such data needs to be converted so it provides 'useful, actionable information about customers, competition and the market' (Lam, et al., 2017:13). To achieve this, the ability to acquire, assimilate, transform and apply big data to create marketing capability (Lam, et al., 2017) is necessary. Lam, et al. (2017) identify three key areas by which big data may be generated within a service context: passive learning; comprehensive customer tracking and business data augmentation with non-business data:

- Passive learning encompasses gathering customer data outside interactions with FLEs (using in-store cameras, cell phone signals and Wi-Fi etc.) to track in-store behaviours and visiting patterns (Brynjolfsson, Hu and Rahman, 2013).

- Comprehensive customer tracking refers to service providers tracking customers outside their physical location (eg., data collected from social networks such as Facebook).

- Business data augmentation with non-business data refers to the integration of business data with data from non-business sources such as face-to-face interaction (eg., voice 
intonations and facial expressions), contextual and situational data (eg., whether customers are in a hurry, whose opinions are sought, etc.) and emotional interpretations.

Small data refers to data collected by FLEs through interactions and relationships with customers (Lam, et al., 2017) and provides deep, rich insights (such as intuition and emotional information) that may be used in a given context. In contrast to big data, small data is generated about specific customers. It is usually characterised as being tacit and unarticulated. Such information is generated through interpersonal interactions in real-time with customers. Marinova, et al. (2017) succinctly capture the characteristics of such interactions insofar as they generate 'rich, unique data that gives rise to FLE know-how... that cannot be possessed readily as a set of hard facts... [and are] characterised by complexity, fragility and tacitness because it is unprocessed, variable, unclear (ambiguous action-outcome links) and thus unscable in its original form' (Marinova, et al., 2017:33).

Cyborgs will have the ability to identify, acquire and assimilate big data provided through passive learning sources, customer tacking and data augmentation integrated with their own intrinsic and tacit knowledge, or small data, acquired through their experiences as FLEs. In other words, they will have both the know what and the know how to utilise in their relationships with customers. They will be able to identify customers along with their preferences, habits and even their current emotional state effectively constructing a ' 360 degree view of the customer' (Grewal and Iyer, 2017). Crucially, and in contrast to Larivière, et al.'s substitution and augmentation technology categories, cyborgs will be able to leverage their intuitive and emphatic intelligence as well as big data analytics to optimise what Bolton, et al. (2014) refer to as the small details of emotional engagement and authenticity through the demonstration of intimacy and passion.

AIs are unlikely to be imbued with emphatic intelligence as a capability in the near future, albeit an area of developing interest (see e.g., Williams, 2018). In contrast to human FLEs, with enhanced levels of intuitive and emphatic intelligence, cyborgs may be able to potentially manipulate elements of their dyadic interaction style to enhance relational satisfaction, encompassing data and decision with humanistic insight. For example, increased rapport may lead to enhanced customer perceptions of 'having enjoyable interaction with a service employee, characterised by a personal connection between the two interactants' (Gremler, 2017:93). Gabriel, et al. (2015) suggest FLEs may leverage emotional displays as part of their 
self-presentation or impression management behaviour. Such displays send signals to potential customers about the FLE's intended behaviours (e.g., to cooperate). Hence, cyborgs may also be capable of leveraging intuitive and emotional intelligence with facial coding technologies to read a customer's emotional state which is then combined with real-time access to background information such as past shopping behaviours and experiences together with instore, service experiences (Lam, et al., 2018) and thereby optimise the moment of truth by utilising deep insight.

\section{Cyborgs as Coordinators and Network Facilitator}

FLEs will increasingly operate within service ecosystems comprising 'configurations of people, technologies, organisations and shared information able to create and deliver value' (Maglio and Spohrer, 2008:18). The services such systems enable will increasingly involve relationships between a diversity of internal and external actors (Gummesson and Grönroos, 2012). For this reason, we see Larivière, et al.'s (2017) categories fusing into a single role whereby cyborg FLEs will act as both coordinator and network facilitator with the blurring of boundaries between firms and markets. Actors will collectively coordinate their behaviour as a complex adaptive system (e.g., Mele and Polese, 2011; Chandler and Lusch, 2015; Engen, et $a l ., 2016$ ) where new entities (human and non-human actors) will be continually joining and leaving a network to ensure service and experiential optimisation ( $\mathrm{Ng}$ and Wakenshaw, 2017). As such, the role of coordinator becomes more significant and more complicated as FLEs coordinate multiple touch points within the ecosystem. Inherent within this is the ability to identify the interaction actor as human, machine or cyborg and leverage an appropriate blend of intelligence (mechanical, analytical, intuitive or empathetic) to ensure system cohesion (Larivière, et al., 2017), facilitation of the network and the optimisation of the customer experience.

\section{Cyborgs as Enablers}

Using big data analytics and small data, cyborgs will be able to audit customer skills, competencies and resources in real time to ascertain the nature and extent of enabling required for a particular service. In contrast to contexts where technology has substituted FLEs, cyborgs will be able to draw on intuitive and emphatic intelligence to leverage their rapport-building behaviour (Geibelhausen, et al., 2014; Bowen, 2016) to socialise and train customers to optimise co-production (Guo, et al., 2013). Hence, cyborgs will circumvent inherent tensions 
of initiatives designed to encourage employee customer rapport with technology substitution at the frontline service boundary (Geibelhausen, et al., 2014).

\section{Cyborgs as Innovators}

Technology cannot substitute human creativity as a source of innovative ideas in either services or their delivery (Motamarri, et al., 2017), albeit AIs are increasingly being used to 'creatively' explore datasets (see e.g., Boden, 2016; du Sautoy, 2019). Interactions with customers help generate service improvement processes through an FLE's ability to 'read' customers' needs (Lages and Piercy, 2012). Therefore, the opportunity for innovation and creative idea generation for service process improvements becomes an integral role of many FLE positions. With cyborgs, these opportunities will be exponentially enhanced through the melding of analytical capabilities, creative insight and human perspective.

Reflecting the themes identified for the melded cyborg, we next examine the research issues that cyborgs as FLEs present within an organisational and service marketing context.

\section{Cyborg as FLEs: A research agenda}

It is evident that cyborg FLEs potentially represent a unique and distinct context for exploring the impact of cyborgs within business contexts. As highlighted above, extant service theory does not adequately capture the essence of how cyborgs may impact service encounters. In proposing a research agenda, we extrapolate on the preceding discussion to reflect key issues related to the nature and roles of cyborgs as FLEs. Specifically, the issues we identify relate to a range of ethical considerations presented by the melded cyborg category of FLE, such as visibility and embeddedness of the technology in use; the roles of transparency and disclosure; use and acceptance of cyborg actors within a firm context; FLE and customer power imbalances; and, privacy and security. We attempt to link emerging research questions in relation to Bowen's (2016) categories, albeit many of the issues proposed transcend all the categories identified at this stage of the research development (see Table 3).

[Insert Table 3 about here]

Visibility-invisibility (perceptibility-imperceptibility) of alteration 
Unlike Larivière, et al.'s augmentation category, melded technologies will be increasingly invisible and imperceptible to another human actor - they operate at a bio- or psychophysical level. Hence, status signification of enhancement or 'super-intelligence' to others (see e.g., Campbell, 2015; Bostrom, 2017) is likely to be a key challenge raising important issues for the firm and their customers in relation to their moral and ethical stance. Whilst technology is used for legitimate purposes, as for example when it replaces a natural organ or supplements the faulty use of a natural organ, the issue of visibility/perceptibility is likely to be of less importance to a firm and customers. However, when alteration in some way enhances natural performance, it is unclear what may be acceptable at firm level or acceptable to customers as an appropriate level of influence. There will be impacts for the firm in areas such as recruitment and training, strategic management and deployment, as well as policy and operations related to FLE activities in areas such as sales and marketing, customer interaction including relationship management, data protection and decision-support - and all these issues must be considered from an ethical/moral and legal standpoint. In all areas of application, the role of the performance-enhanced cyborg FLE is likely to add differentiating value (Bowen's Differentiator category) to the firm through interactions and interpersonal relationships. With enhanced interactions between cyborg FLEs and customers, firms are likely to have enhanced expectations of relational outcomes that include soft (e.g., satisfaction and trust) and financial benefits, leading to longevity and competitive advantage through continuous improvement (enabling and facilitation) and innovation. It is when the enhancement becomes a required competency or skill necessary for the fulfilment of FLE roles that ethical issues are likely to become particularly pertinent for all stakeholders. For example, in effectively managing data that may facilitate or enable interactions, or lead to new innovations which may also involve third party suppliers to cyborgs (Bowen's Coordinator/Networker, Enabler and Innovator categories). Moreover, when presented with superintelligence, and the enhancement is invisible or imperceptible, then the uncanny valley effect appears to be an irrelevant theoretical construction in such contexts (Bostrom, 2016).

\section{Disclosure and transparency of alteration to others}

Related to the above are ethical issues around appropriate levels of alteration transparency and how these are signified to both customers and other FLEs (related to Bowen's categories). Since scientific developments of biowearables have been fundamentally driven by the impetus to improve quality of life for humans with life-limiting problems for restorative purposes, a starting point for this is to reflect upon the disability/ability management literature. At a firm 
level, literature tends to emphasise equality and diversity relating to Human Rights Principles in the integration of impaired (disabled) employees into the workforce (eg., Usdiken and Leblebici, 2001). Williams and Mavin (2012) argue that disability is a constructed difference that categorises people into social hierarchies (e.g., West and Fenstermaker, 2002). It is the normalisation of these hierarchies within a firm that influences how people relate to others - a disabled person being 'other'. Disability is therefore often framed against normalcy and normality (eg., Oliver 2009; Williams and Mavin, 2012) whereas medicalised discourse relating to the use of technologies for repair typically relates to adaptation and rehabilitation at work (French 2001). In inversing this argument with a requirement for a declarative statement of alteration and enhancement, necessitated by, for example, demands for transparency in how data is managed, cyborgs also become a social category of 'other'. Their identity therefore becomes value-laden and subject to some process of organisation within a firm, in much the same way as management literature integrates structures for disability. Ultimately, this has implications for how cyborgs view themselves and their social context as well as how others (employees and customers) view them.

Whilst a long-range view may consider that all humans will become cyborg in some way (and indeed, we probably already are, see e.g., Clarke, 2003), this point hints that there is clearly a need for conceptualising the cyborg as an employee/FLE at interim stages of technological advancement, or embodied nature of technological alteration and its capabilities. One argument for this relates to the current use of drugs for recreational, body building, quality of life management and disease control. Such transformations that drugs render are often seen by users and others as beneficial and are contextualised in terms of functional health and wellbeing (Blackford, 2013). At what point therefore does the alteration by contemporary technology exceed 'appropriate' or 'exceptional'? Moreover, in whose interest is declaration of alteration required? In the drug example, the point at which firms may become involved with the use of steroid drugs to enhance muscle mass is often a matter of apparent or declared abuse which typically manifests as mental health concerns. In contrast, medical drugs to control disease manifests itself through abstention from work as a consequence of illness. Declaration therefore benefits both the employer and employee in different ways at varying points in times. The use or abuse of contemporary technologies may well differ from these scenarios. For example, the misuse of emphatic knowledge. Furthermore, since alterations that incorporate contemporary technologies are likely to come at a considerable cost (time and financial) to the user (at the moment, cyborgs are made rather than born) and benefit to both employer and 
employee, there are likely to be ethical considerations around affordability and instrumentality that extend the definitions of equality and diversity to include cyborg FLEs. In so doing, it implies a necessary level of transparency and declaration of cyborg status. This raises questions about the types of declaration clauses that firms and employees may be required to use and how, in turn, equality and diversity in this evolving framework is operationalized and impacts stakeholders - we list research questions that may be appropriate for consideration in each of Bowen's categories in Table 3.

\section{Customer acceptance of cyborgs as FLEs}

When considering cyborg FLEs, there is a need to step beyond the current rhetoric of technology acceptance and adoption. Contemporary models such as Technology Acceptance Model (TAM, see Davis, et al., 1989) and its extensions that reflect the usefulness and accessibility of technologies as tools that may augment (such as UTAUT/2, see Venkatesh, et al., 2003; 2016), they do not adequately reflect or capture cyborg status or how it potentially influences interactions and relationships with others (Bowen, 2016; Shaw, et al., 2018). Given the embodied nature and increasingly performance-enhancing capability of technological advancements highlighted, it is the advantages afforded by these technologies and the influence these will exert that will be significant from an acceptance perspective. Within the service literature, preliminary research suggests there is general customer fear of human-robot hybridity. Bhattacharyya and Kedzior (2012) found that technology users believed they may lose their humanness in becoming cyborg, despite overcoming perceived natural flaws and potentially being transcended to a 'godlike' status that fuses mind, body and spirit with technology (Belk, 2016; Galeon and Reedy, 2017). This could well be reflected in customer attitudes towards cyborg FLEs.

From the perspective of a customer or colleague, the 'uncanny valley' theory of revulsion and 'decent into eeriness' (eg., Mori, 1970) is a variable that is largely unexplored in the domain of cyborgs. Extant literature highlights that feelings of unease are evoked as a consequence of form and unnatural interaction, say where speed or process of some motor action is unusual, rather than a function per se. This is clearly associated with the visibility of technological enhancement, and often contextualised to robots and autonomous devices. In service contexts, human interaction (face-to-face) is a preferred because synthetic devices are perceived to be inadequate communication devices in situations where highly personalised service is desired. With cyborgs, alteration increases autonomy and quality of service experience, however, 
biomechanical movement and interaction performance are changed in ways that will possibly be perceptible to others as the capabilities increase with technological advancements. It is unclear to what extent this will impede FLE-customer interactions. Suffice to say it is likely to be a function of the levels of cyborg integration within service contexts more broadly, the general use and acceptability of technologies by customers (Harwood and Garry, 2017) and the extent to which alterations and cyborgism becomes a natural human state. Hence, there are three different perspectives from which researchers need to conceptualise and explore acceptance and tolerance-in-use: the firm, the customer and the cyborg FLE, as well as reflecting the broader views of society at large. Fundamentally, in extrapolating FLE roles, acceptance of technological embodiment, interpersonal trust, use of information and management of super intelligent service actors are areas for exploration related to Bowen's categories (Table 3).

\section{FLE-customer power balances}

This paper has focussed on the role of FLEs as cyborg whilst ignoring any reference to cyborg customers. Cyborgs may of course also be customers as well as FLEs, with different levels of alteration providing either or both FLE and customer with potentially more capability to exploit competence, knowledge and/or resources. This may be particularly the case with interactions that lead to ongoing relationships (e.g., Wirtz, et al., 2018). The trajectory of technological advancement and cyborg evolution is likely to lead to situations where, at least in the early stages of development, there is an imbalance in the nature of the relationship and modes of interaction as a consequence of cognitive and emphatic capacities and biophysical properties. As Blackford (2013) argues, alongside the obvious advantages of superior intelligence demonstrated through the ability to rapidly and accurately respond to complex or difficult circumstances, health and wellbeing that leads to personal longevity is also a form of power that may be exploited.

It is only when the balance of alteration is on a par that any interaction is likely to be synergistic or interdependent. However, given the points highlighted in the previous paragraphs, it is most likely there will always be power imbalance that must be managed through a moral and ethical lens at both firm and individual levels (see Table 3, Bowen's categories). FLEs are likely to be employed as enhanced actors in order to provide improved and exploitable competitive advantages for the firm/brand in domain specific contexts (e.g., Nyholm, 2018). In such circumstances, new classes of inter-relational capacities will need to be understood. For 
example, although customer perceptions will be strongly linked to firm/brand values, customer perceived levels of transparency in cyborg behaviour and data management will be needed to signify customers are being treated fairly and reasonably. The context of data use by the cyborg FLE and firm/brand must be clearly understandable. This may require permissive use of different types of data to maintain trust albeit that where knowledge is similarly attainable by the both the cyborg FLE and the customer then trust, at least in its traditional social relational form, potentially becomes irrelevant - because knowledge is exploitable equally by each. Thus, at the interaction level, there will be a need to critically re-evaluate the parameters of relational influence to assess the appropriateness of cyborg FLE behaviour and customer perceptions.

Furthermore, a number of interrelated questions arise that transcend Bowen's categories (Table 3) and require future investigation in each transformational role as well as from the different perspectives of firm, customer and employee that impact policy and operational aspects of their use in business:

- Operational considerations -

What are the perceived balance of power issues in engaging with cyborg FLEs as brand 'custodians'?

What are the [de-]motivations for engaging with an enhanced performance cyborg FLE?

What makes cyborg FLEs trustworthy, or indeed trust irrelevant within such contexts (trust being a form of personal power)?

- Policy considerations -

How will power interdependencies be leveraged or indeed, potentially exploited?

How will cyborg FLE alterations be made understandable and be understood by customers? How will moral/ethical judgment in cyborg FLE interaction be identified and demonstrated to deliver fair and equitable experiences?

\section{Privacy and security}

The potential for cyborg FLEs to access big and small data simultaneously in real-time and render it so as to exert influence (over humans, cyborgs, robots) within service contexts has received little attention in the literature to date. Consequently, ethical questions arise about how firms/brands may integrate cyborg FLEs into propositions (see Table 3 for examples of issues highlighted within Bowen's categories). The issues of privacy and security pertain, primarily, to the significance of the types of data and data access/usage (Quigley and 
Ayihongbe, 2018). With technological advancements enabling increasingly complex tasks to be performed, such as those highlighted in Tables 1 and 2, privacy relates differentially to device/system software (programmes and instructions on how the device is to work), connectivity to other devices; modes of storage, transmission and usage, the identity and status of the human, and functionality of the device itself (see e.g., Burri and Senouf, 2009). Access to device-related data may well be appropriate to monitor safety and tolerance levels but the boundaries of personal data in the context of cyborg FLEs is difficult to determine: what data relates to personal performance (e.g., health status) and who has access in managing that information effectively is far from clear in a firm/brand context employing cyborg FLEs.

With regard to security, hacking and modification of technologies has become commonplace and cybersecurity in particular is now a major concern for firms. Where technologies have been used to alter the capacities of an individual by that individual, and there is no requirement for declarative interest as an employee, then there are likely to be significant concerns over malicious attacks against individuals to interrupt or influence their performance (e.g., anon $\mathrm{BBC}$, 2017). Moreover, at least in the near future, enhancements and improvements are being undertaken at a personal rather than an employer level. Yet where the target of an attack is the firm or their customers and suppliers accessed through a cyborg FLE it is unclear who may be responsible or how consequential action or remedy may be apportioned. It is therefore appropriate to reflect categories such as Bowen's (2016) in order to classify the impacts of consequences on those affected.

\section{Conclusion}

With a number of researchers (e.g., Blackford, 2013; Galeon and Reedy, 2017) predicting cyborgs will become the dominant form of service provider in the near future, this paper aimed to draw attention to the most pertinent issues faced by the employment of cyborgs as FLEs. Recent research has tended to concentrate on classifications of technology 'infusions' (automated social presence actors) without recognizing human-machine hybrids (van Doorn, et al., 2017; Wirtz, et al., 2018). Extending Larivière, et al.'s (2017) categories of technology infusions in service encounters, this paper has conceptualized a new category of cyborg FLE, melding, and highlighted how emergent technological advancements will alter humans' bioand psycho-physical properties. In turn, these technological alterations may influence the nature of service interactions and the transformational roles categorised by Bowen (2016) in profound ways: we explore issues related to service complexity, co-production and co-creation, 
productivity, efficiency, efficacy and problem solving as well as inter-relational outcomes (e.g., Huang and Rust, 2018; Wirtz, et al., 2018).

Technological advancements resulting in changes to form and behaviour will raise important questions for the firms/brands that will be the first to employ cyborg FLEs to support service delivery. This is not least because of the significant potential benefits to firm operations through the customer insights they may gain by the employment of cyborg FLEs (e.g., van Doorn, et al., 2017; Belk, 2016). In this paper, we have outlined how such technologies may initially impact on common methods of technology application related to forms of mechanical and analytical intelligence, where processing data to increase productivity is a focus (Huang and Rust, 2018). However, such technologies as those presented in Table 1 will ultimately become entwined with the unique skillsets of humans to intuitively and empathetically address complex socio-relational problems (Table 2).

\section{Implications for Theory}

Whilst the adoption of automated robots with high levels of anthropomorphic reasoning can result in uneasiness (the 'uncanny' effect), the increasingly fuzzy distinction between human and machine as cyborg may, at least initially, reduce feelings of uncanniness (e.g., Herr, 2014; Gibson, 2017) - cyborgs are not robots, and as we have highlighted it will be increasingly difficult to differentiate the melded human cyborg from the unenhanced human. Our review has highlighted how cyborgs potentially sidestep the many and various issues that the use of robots in FLE contexts present. We also identify a number of key areas which present significant ethical and moral dilemmas, set out as a research agenda. These require further conceptualisation and investigation and we acknowledge this is by no means a fully comprehensive exploration of issues. In this paper we have attempted to highlight the ways in which the cyborg FLE is likely to differ from unenhanced human actors and in so doing draw attention primarily to theories that relate to interpersonal interaction in business-to-customer contexts: trust, relational exchange, roles of actors. It is clear, however, that there is much work required to develop relevant theories which incorporate technological advancements that assimilate superintelligence with business processes in service market contexts.

\section{Implications for Practice}

Our review has focussed on the nature of interactions including the implications of visibilityinvisibility of cyborg alteration; the need for disclosure and transparency of cyborg FLE status 
to others; how acceptance of cyborg FLE actors may be explored; issues of privacy and security raised by the embodied nature of the technologies and likely implications for firms in their employment in FLE contexts, customers in their interactions with cyborg FLEs and employees as cyborg FLEs. With technologies advancing beyond the scope of societal and government intervention, it is likely that it will fall to businesses to make decisions in the first instance on key issues such as how, when and where such technologically advanced cyborgs will be employed. Body hacking and modification has already become a social phenomenon that is attracting a growing following of people who are willing, and have the resources, to actively participate in this emergent digital cultural practice, despite a lack of regulation and good practice in interventions (see, for example, Royal Society, 2019). Thus, consumers will derive demand for technological alterations, but businesses must be aware of the possible consequences, both positive and negative, that will arise from their integration into operations, particularly where they are employed as FLEs and thus have potential to acquire and utilize unique insight into customers.

\section{References}

Adams, T. (2017), "When man meets metal: rise of the transhumans", The Guardian, 29 Oct, available at https://www.theguardian.com/technology/2017/oct/29/transhumanbodyhacking-transspecies-cyborg (accessed $12 \mathrm{Sept}$ ).

Anderson, C., Keltner, D., and John, O.P. (2003), "Emotional convergence between people over time", Journal of Personality and Social Psychology, Vol. 84 No. 5, pp. 10541068 .

Anon BBC (2017), "Cyber-flaw Affects 745,000 Pacemakers", BBC News, 30 Aug 2017, available online at http://www.bbc.co.uk/news/technology-41099867 [accessed 25 Oct 2018].

Argyris, C. and Schön, D.A. (1978), Organizational Learning. Reading, MA: AddisonWesley.

Ascott, R. (2013), "Back to Nature II: Art and technology in the $21^{\text {st }}$ Century", in More, M and Vita-More, N., The Transhumanist Reader, pp. 438-448, Chichester: WileyBlackwell.

Batchelar, D.A. (2018), "Welcome to the Singularity, who can say no to the hive mind's promise of cybernetic immortality, for free?", Communications of the ACM, Vol. 61 No 2, pp. 104-105.

Belk, R. (2016), "Understanding the Robot: Comments on Goudey and Bonnin”, Recherche et Applications en Marketing, Vol. 31 No. 2.

Belk R. (2017), "Consumers in an Age of Autonomous and Semi-Autonomous Machines", in Sherry, J. Jr. and Fischer, E. eds., Currents in Consumer Culture Theory, pp. 5-32, London: Routledge.

Belk, R. (2018), "Robots, Cyborgs, and Consumption”, in Lewis, A. ed., Cambridge Handbook of Psychology and Economic Behaviour, pp. 741-758, Cambridge: Cambridge University Press. 
Berry, L.L. (1995), "Relationship Marketing of Services - Growing Interest, Emerging Perspectives", Journal of the Academy of Marketing Science, Vol. 23 No. 4, pp. 236245.

Bettencourt, L., Brown, S. and Mackenzie, S. (2005), "Customer-orientated boundaryspanning behaviors: test of a social exchange model of antecedents", Journal of Retailing, Vol. 81 No. 2, pp. 141-157.

Bhattacharyya, A. and Kedzior, R. (2012), "Consuming the Cyborg", in Gürhan-Canli, Z., Otnes C. and Zhu, R. (eds.), Advances in Consumer Research, Vol. 40, pp. 960-961, $\mathrm{MN}$ :. Duluth.

Bitner, M. J. (1990), "Evaluating Service Encounters: The Effects of Physical Surroundings and Employee Responses", Journal of Marketing Management, Vol. 54 (April), pp. 69 $-82$.

Blackford, R. (2013), "The Great Transition”, in More, M and Vita-More, N., The Transhumanist Reader, pp. 421-429, Chichester: Wiley-Blackwell.

Boden, M. (2016), AI: Its nature and Future, Oxford: Oxford University Press.

Boden, M. (2017), Panellist: “Are we ready for robot relationships?” British Academy Lecturer Series: Robotics, AI and Society, 2 Feb, De Montfort University, Leicester, UK.

Bolton, R., Gustafsson, A., McColl-Kennedy, J., Sirianni, N. and Tse, D.K. (2014), "Small details that make big differences: A radical approach to consumption experience as a firm's differentiation strategy", Journal of Service Management, Vol. 25 No. 2, pp. 253-274.

Bostrom, N. (2017), Superintelligence: paths, dangers, strategies, Oxford: Oxford University Press.

Bowen, D. (2016), "The Changing Role of Employees in Service Theory and Practice: An Interdisciplinary View", Human Resource Management Review, Vol. 26 No.1, pp. 413.

Brynjolfsson, E., Hu Yu, J. and. Rahman, M. (2013), “Competing in the Age of Omnichannel Retailing”, MIT Sloan Management Review, Vol. 54 No. 4, pp. 23-29.

Buchanan-Oliver, M., Cruz, A. and Schroeder, J. (2010), "Shaping the Body and Technology: Discursive Implications for the Strategic Communication of Technological Brands", European Journal of Marketing, Vol. 44 No. 5, pp. 635-652.

Burri, H. and Senouf, D. (2009), "Remote monitoring and follow-up of pacemakers and implantable cardioverter defibrillators", Europace, Vol. 11, pp. 701.

Campbell, N., Deane, C. and Murphy, P. (2015), “Advertising nanotechnology: imagining the invisible", Science, Technology and Human Values, pp. 1-33.

Caprino, K. (2012), “What You Don't Know Will Hurt You: The Top 8 Skills Professionals Need to Master," Forbes, 27 April, available at https:/www.forbes.com/sites/kathycaprino/2012/04/27/what-you-dont-know-willhurt-you-the-top-8-skills-professionals-need-to-master/\#3d7a0bf4412d (accessed 29 Oct 2018)

Chandler, J.D. and Lusch, R.F. (2015), "Service Systems: A Broadened Framework and Research Agenda on Value Propositions, Engagement, and Service Experience", Journal of Service Research, Vol. 18 No. 1, pp. 6-22.

Chen, T.L., Bhattacharjee, T., McKay, J.L., Borinski, J.E., Hackney, M.E., Ting, L.H. and Kemp, C.C. (2015), "Evaluation by Expert Dancers of a Robot That Performs Partnered Stepping via Haptic Interaction”, PLoS One, Vol. 10 No. 5, e0125179. 
Cirkovic, M.M. (2017), "Enhancing a person, enhancing a civilization: a research program at the intersection of bioethics, future studies and astrophysics", Cambridge Quarterly of Healthcare Ethics, Vol. 26 No. 3, pp. 459-468.

Clark, A. (2003), Natural Born Cyborgs: Minds, Technologies, and the Future of Human Intelligence, Oxford: Oxford University Press.

Clough, P. (2008), "The affective turn: political economy, biomedia and bodies", Theory, Culture and Society, Vol. 25 No. 1, pp. 1-22.

Coelho, F. and Augusto, M. (2010), "Job Characteristics and the Creativity of Frontline Service Employees", Journal of Service Research, Vol. 13 No.4, pp. 426-428.

Cortellessa, G., Fracasso, F., Sorrentino, A., Orlandini, A., Bernardi, G., Coraci, L., De Benedictis, R. and Cesta, A. (2018), "ROBIN, a Telepresence Robot to Support Older Users Monitoring and Social Inclusion: Development and Evaluation", Telemed J E Health, Vol. 24 No. 2 pp. 145-154.

Davenport, T.H. and Prusak, L. (2000). Working Knowledge: How Organizations Manage What They Know. Boston, MA: Harvard Business School Press

Davis, F. D., Bagozzie, R. P. and Warshaw, P. R. (1989), "User acceptance of computer technology: A comparison of two theoretical models authors", INFORMS, Vol. 35 No. 8, pp. 982-1003.

De Keyser, A., Köcher, S., Alkire, L., Verbeeck, C. and Kandampully, J. (2019), "Frontline Service Technology infusion: Conceptual archetypes and future research directions", Journal of Service Management, Vol. 30 No. 1, pp. 156-183.

Dorfler, V. and Ackermann, F. (2012), "Understanding intuition: the case of two forms of intuition", Management Learning, Vol. 43 No. 5, pp. 545-564.

Du Sautoy, M. (2019), The Creativity Code, London: $4^{\text {th }}$ Estate.

Dupuy, J.-P. (2011), "Cybernetics is antihumanism: advanced technologies and the rebellion against the human condition", in Hansell, G.R. and Grassie, W., Transhumanism and its Critics, pp. 227-248, Philadelphia PA: Metanexus Institute.

Engen, V., Pickering, J. B. and Walland, P. (2016), "Machine Agency in Human-Machine Networks; Impacts and Trust Implications", arXiv preprint arXiv:1602.08237.

Eveleth, R. (2016), "Why Did I Implant A Chip In My Hand? My So-called Cyborg Life", Popular Science available at http://www.popsci.com/my-boring-cyborg-implant (accessed 27 Jul 2018).

Firger J. (2016), "'Tec Tats' Usher in New Generation of Wearables", Newsweek, available at $\mathrm{http}$ ://europe.newsweek.com/tech-tats-usher-new-generation-wearables- 401536?rm=eu (accessed 27 Jul 2018).

Ford, M. (2017), "Driverless trucks: economic tsunami may swallow one of the most common US jobs", The Guardian, 16 Feb, available at https://www.theguardian.com/technology/2018/feb/16/self-driving-trucks-automationjobs-trucking-industry?CMP=share btn tw (accessed $30^{\text {th }}$ October 2018).

French, S. (2001), Disabled People and Employment. A Study of the Working Lives of Visually Impaired Physiotherapists, Aldershot: Ashgate.

Gabriel, A.S., Acosta, J.D. and Grandey, A.A. (2015), “The value of a smile: Does emotional performance matter more in familiar or unfamiliar exchanges?" Journal of Business and Psychology, Vol. 30, pp. 37-50.

Gabriel. A.S., Cheshin, A., Moran, C.M. and Van Kleef, G.A. (2016), "Enhancing emotional performance and customer service through human resources practices: a systems perspective", Human Resource Management Review, Vol. 26 No.1, pp. 14-24.

Galeon, D. and Reedy, C. (2017), "Kurzweil claims that the singularity will happen by 2029", The Futurist, available at https://futurism.com/kkurzweil-claims-that-the-singularitywill-happen-by-2029/ (accessed 16 March 2018). 
Gardner, H. (1983), Frames of Mind: The Theory of Multiple Intelligence. New York: Basic Books.

Garry, T. and Harwood, T. (2009), "The Moderating Influence of Client Sophistication on Relationships within Business-to-Business Credence Service Markets", Journal of Business and Industrial Marketing, Vol. 24 No. 5\&6, pp. 380-388.

Geibelhausen, M., Robinson, S., Sirianni, N. and Brady, M. (2014), "Touch versus tech: When technology functions as a barrier or a benefit to service encounters", Journal of Marketing, Vol. 78 No.4, pp. 113-124.

Gibson, R. (2017), "More than merely human: how science fiction pop-culture influences our desires for the cybernetic", Sexuality and Culture, Vol. 21, pp. 224-246.

Goleman, D. (1996), Emotional Intelligence: Why It Can Matter More than IQ. London, UK: Bloomsbury Publishing.

Grandey, A.A., Fisk, G.M. and Steiner, D.D. (2005), "Must "service with a smile" be stressful? The moderate role of personal control for American and French employees", Journal of Applied Psychology, Vol. 90 No. 5, pp. 893-904.

Gremler, D. (2017), "Cultivating Interpersonal Connections with Customers: When Might 'High Touch' Trump 'High High Tech'? in The Future of Frontline Research: Invited Commentaries", Journal of Service Research, Vol. 20 No.1, pp. 93.

Grewal, D., and Iyer, B. (2017), "The Age of Smart Products and Services: Changing Expectations in The Future of Frontline Research: Invited Commentaries", Journal of Service Research, Vol. 20 No.1, pp. 95-96.

Grönroos, C. (1984), "A Service Quality Model and its Marketing Implications", European Journal of Marketing, Vol. 18 No. 4, pp. 36-44,

Groth, M., Wu, Y., Nguyen, H. and Johnson' A., (2019), "The Moment of Truth: A Review, Synthesis, and Research Agenda for the Customer Service Experience", The Annual Review of Organizational Psychology and Organizational Behavior, Vol. 6, pp. 89-113.

Gummesson, E. and\& Grönroos, C. (2012), "The emergence of the new service marketing: Nordic School perspectives", Journal of Service Management, Vol. 23 No.4, pp. 479497.

Guo, L., Arnould, E., Gruen, T. and Tang C. (2013), "Socializing to co-produce" Journal of Service Research, Vol. 16, No. 4, pp. 549-56.

Haraway, D. (1985), “A Manifesto for Cyborgs: Science, Technology, and Socialist Feminism in the 1980s", Socialist Review, 80, 65-107.

Hartley, G. (2018), Fed Up: Emotional Labor, Women, and the Way Forward, London: Yellow Kite.

Harwood, T and Garry, T. (2017), "'Internet of Things: Understanding trust in techno-service systems", Journal of Service Management, Vol. 28 No. 3, pp. 442-475.

Hennig-Thurau, T., Groth, M., Paul, M. and, Gremler, D.D., (2006), "Are all smiles created equal? How emotional contagion and emotional labor affect service relationships", Journal of Marketing, Vol. 70, No. 3, pp. 58-73.

Herr, H. (2014), "The new bionics that let us run, climb and dance", Ted Talk, https://www.ted.com/talks/hugh_herr_the_new_bionics_that_let_us_run_climb_and_ dance (accessed 27 Jul 2018).

Heskett, J, Sasser, W. and Schlesinger, L. (1997), The service profit chain: How leading companies link profit and growth to loyalty, satisfaction, and value, New York: The Free Press.

Hofman, B., Haustein, D. and Landeweerd, L. (2016), "Smart glasses: exposing and elucidating the ethical issues", Science Engineering Ethics, Vol. 23, pp. 701-721. 
Homburg, C. and Stock R. (2004), "The Link between Salespeople's Job Satisfaction and Customer Satisfaction in a Business-to-Business Context: A Dyadic Analysis", Journal of the Academy of Marketing Science, Vol. 32 No. 2, pp. 144-158.

Huang, M. and Rust, R. (2018), “Artificial Intelligence in Service”, Journal of Service Research, Vol. 21 No. 2, pp. 155-172.

Ihde, D. (2008), “Of which humans are we post?”, The Global Spiral, Vol. 9/3 (June), available at www.metanexus.net/magazine/tabid/68/id/10552/defalt.aspx (accessed 30 July 2019).

Jayanti, K. and Singh, J. (2010), "Pragmatic Learning Theory: An Inquiry-Action Framework for Distributed Consumer Learning in Online Communities", Journal of Consumer Research, Vol. 36 (April), pp. 1058-1081.

Johnson, H., (2014), “6 Soft Skills Every Professional Needs,”, OnlineDegrees.com, 17 October 17, available at https://futurism.com/majorfirmannouncesitsreplacin gitsemployeeswithai/ (accessed 24 Jan 2017).

Kiffin-Petersen, S., Murphy, S. and Soutar, G., (2012), "The problem-solving service worker: Appraisal mechanisms and positive affective experiences during customer interactions", Human Relations Vol. 65 No. 9, pp. 1179-1206.

Lages, C. and Piercy, N. (2012), "Key drivers of frontline employee generation of ideas for customer service improvement", Journal of Service Research, Vol. 15, pp. 215-230.

Lai, J., Lui, S.S. and Hon, A.H.Y. (2014), "Does standardized service fit all? novel service encounter in frontline employee-customer interface", International Journal of Contemporary Hospitality Management, Vol. 26 No. 8, pp. 1341-1363.

Lam, S., Sleep, S., Hennig-Thurau, T., Sridhar, S. and Saboo, A. (2017), "Leveraging Frontline Employees' Small Data and Firm-Level Big Data in Frontline Management: An Absorptive Capacity Perspective", Journal of Service Research, Vol. 20 No. 1, pp. 12-28.

Larivière, B., Bowen, D., Andreassen, T., Werner, K., Sirianni, N., Voss, C., Wünderlich N. and, De Keyser, A., (2017), "Service Encounter 2.0: An Investigation into the Roles of Technology, Employees and Customers", Journal of Business Research, Vol. 79, pp. 238-246.

Lem, S. (1977), Summa Technologiae. Belgrade: Nolit.

Lovelock, C., (1981), in Donnnelly, J. and George, W. (eds.), Why marketing management needs to be different for services, Chicago: American Marketing Association, Chicago.

Lovelock, J. (2019), Novacene, New York: Allan Lane Publishing.

Macdonald, E. and Uncles, M. (2007), "Consumer savvy: conceptualisation and measurement”, Journal of Marketing Management, Vol. 23, No. 5-6, pp. 497-517.

Maglio, P.P. and Spohrer, J. (2008), "Fundamentals of Service Science”, Journal of the Academy of Marketing Science, Vol. 36, pp. 18-20.

Marinova, D., de Ruyter, K., Huang, M., Meuter, M. and Challagalla, G. (2017), "Getting Smart: Learning from Technology Empowered Frontline Interactions", Journal of Service Research, Vol. 20 No.1, pp. 29-42.

McAfee, A. and Brynjolfsson, E. (2012), "Big Data: The Management Revolution", Harvard Business Review, Vol. 90 No.10, pp. 61-67.

Mele, C. and Polese, F. (2011), "Key dimensions of service systems in value-creating networks", in Demirkan, H., Spohrer, J.C. and Krishna, V. (eds.), The Science of Service Systems, pp. 37-59, New York, NY: Springer.

Monks, K. (2014), "Forget Wearable Tech, Embeddable Implants Are Already Here", CNN, available at http://edition.cnn.com/2014/04/08/tech/forget-wearable-tech-embeddableimplants/ (accessed 27 Jul 2018). 
More, M. (2010), "The overhuman in the transhuman", Journal of Evolution and Technology, Vol. 21/1 (January), pp. 1-4.

Mori, M. (1970), The uncanny valley (tr. MacDorman, K.F. and Kageki, N. 2015), available online at http://web.ics.purdue.edu/ drkelly/MoriTheUncannyValley1970.pdf (accessed 22 October 2018).

Motamarri, S., Akter, S. and Yanamandram, V. (2017), "Does big data analytics influence frontline employees in services marketing?" Business Process Management Journal, Vol. 23, No. 3, pp. 623-644.

Mouthuy, P.-A. and, Carr, A. (2017), "Growing tissue grafts on humanoid robots: a future strategy in regenerative medicine?" Science Robotics, Vol. 2 No. 4, DOI: 10.1126/scirobotics.aam5666.

Muller, M.U. (2018), "Playing doctor with Watson: Medical application expose current limits of AI", Spiegel Online, available at http://www.spiegel.de/international/world/playingdoctor-with-watson-medical-applications-expose-current-limits-of-ai-a-1221543.html (accessed 22 October 2018).

Oliver, M. (2009), Understanding Disability: From Theory to Practice, 2nd ed., Basingstoke: Palgrave Macmillan.

Peters, T. (2008), "Transhumanism and the posthuman future: will technological progress get us there?", The Global Spiral, Vol. 9/3 (June), available at www.metanexus.net/magazine/tabid/68/id/10546/default.aspx

Pugh, S. (2001), "Service with a Smile: Emotional Contagion in the Service Encounter," Academy of Management Journal, Vol. 44 No. 5, pp. 1018-1027.

Quigley, M. and Ayihongbe, S. (2018), "Everyday cyborgs: on integrated persons and integrated goods", Medical Law Review, Vol. 26 No. 2, pp. 276-308.

Royal Society (2019), iHuman: blurring lines between mind and machine, available at https://royalsociety.org/-/media/policy/projects/ihuman/report-neural-interfaces.pdf (accessed 12 Sept), The Royal Society, London, Sept.

Rust, T. and Oliver, R. (1994), "Service Quality: Insights and Managerial Implications from the Frontier," in Rust, R.T. and Oliver, R.L. (eds.), Service Quality: New Directions in Theory and Practice, pp. 1-19, London, UK: Sage.

Schlesinger, L.A. and Heskett, J.L. (1991), "Breaking the cycle of failure in services", Sloan Management Review, Vol. 32 No. 3, Spring, pp. 17-28.

Schneider, B. and Bowen, D. (1999), "Understanding Customer Delight and Outrage", Sloan Management Review, Vol. 41 No. 1, Fall, pp. 35-45.

Shaw, J.A. (2015), "From homo economicus to homo roboticus: an exploration of the transformative impact of the technological imaginary", International Journal of Law in Context, Vol. 51 No. 3, pp. 281-297.

Sierra, J. J. and, \& McQuitty, S. (2005), "Service providers and customers: social exchange theory and service loyalty", Journal of Services Marketing, Vol. 19 No. 6, pp. 392400.

Singh, J., Brady, M., Arnold T. and Brown, T. (2017), "The Emergent Field of Organizational Frontlines", Journal of Service Research, Vol. 20 No.1, pp 3-11.

Sparrow, B. Liu, J. and Wegner, D.M. (2011), "Google Effects on Memory: Cognitive Consequences of Having Information at Our Fingertips", Science, Vol. 333 (6043), pp. 776-778.

Sternberg, R.J. (2005), “The Theory of Successful Intelligence,” Interamerican Journal of Psychology, Vol. 39 No. 2, pp. 189-202.

Subramony, M. and Pugh, D. (2015), "Services management research: Review, integration, and future directions", Journal of Management, Vol. 41 No. 1, pp. 349-373.

Tzafestas, S.G. (2018), "Roboethics: fundamental concepts and future prospects, Information, 
Vol. 9 No. 6, p. 148, doi 10.3390/info9060148.

Üsdiken, B. and ve Leblebici, H. (2001), "Organization theory”, in Anderson, N.D., Ones, D., Sinangil, H.K. and Viswesvaran ve C. (Der.) (eds.), International Handbook of Work and Organizational Psychology, pp. 377-397.2, Cilt. Newbury Park, CA: Sage. van Doorn, J., Mende, M., Noble, S.M., Hulland, J., Ostrom, A.L., Grewal, D. and Petersen, J.A. (2017), "Domo arigato Mr Roboto: emergence of automated social presence in organizational frontlines and customers services experiences", Journal of Service Research, Vol. 2 No. 1, pp. 43-58.

Venkatesh, V., Morris, M.G., Davis, G.B. and Davis, F.D. (2003), "User acceptance of information technology: Toward a unified view”, MIS Quarterly, Vol. 27 No.3, pp. 425-478.

Venkatesh, V., Thong, J. and Xu, X. (2016), "Unified theory of acceptance and use of technology: a synthesis and the road ahead", Journal of the Association for Information Systems, Vol. 17 No. 5, pp. 328-376.

Warwick, K. (2003), "Cyborg morals, cyborg values, cyborg ethics", Ethics and Information Technology, Vol. 5, pp. 131-137.

West, C. and Fenstermaker, S. (2002), "Reply - (re)doing gender", in Fenstermaker, S. and West, C. (eds.), Doing Gender, Doing Difference. Inequality, Power and Institutional Change. pp. 95-101, New York: Routledge.

Williams, D. (2018), "The rise of emotional robots", Sapiens, 28 August, available at https://www.sapiens.org/technology/emotional-intelligence-robots/ (accessed 28 Aug 2019).

Williams, J. and Mavin, S. (2012), "Disability as constructed difference: a literature review and research agenda for management and organization studies", International Journal of Management Reviews, Vol. 14 No. 2, pp. 159-179.

Winkler, R. (2017), "Elon Musk Launches Neuralink to Connect Brains with Computers," The Wall Street Journal, 27 March, available at https://www.wsj. com/articles/elonmusk-launches-neuralink-to-connect-brainswith-computers-1490642652 (accessed 30 Oct 2018).

Wirtz, J. and Jerger, C. (2016), "Managing service employees: Literature review, expert opinions, and research directions", The Service Industries Journal, Vol. 36 No. 15-16, pp. 757-788.

Wirtz, J., Patterson, P., Kunz, W., Gruber, T., Lu V.N., Paluch, S. and Martins, A. (2018), "Brave new world: service robots in the frontline", Journal of Service Management, Vol. 29 No. 5. DOI 10.1108/JOSM-04-2018-0119.

Yim, C., Tse, D. and Chan, W. (2008), "Strengthening customer loyalty through intimacy and passion: Roles of customer-firm affection and customer-staff relationships in services", Journal of Marketing Research, Vol. 45 (December), pp. 741- 756.

Zeithaml, V. Parasuraman, A. and Berry, L. (1985), "Problems and strategies in services marketing", Journal of Marketing, Vol. 49, pp. 33-45.

Zhang, A. and Lieber, C.M. (2016), "Nano-bioelectronics", Chemical Review, Vol. 116, pp. 215-257. 


\section{Table 1: Contemporary technological advancements for human enhancement}

\begin{tabular}{|c|c|c|}
\hline $\begin{array}{c}\text { Category of } \\
\text { Technological } \\
\text { Advancement }\end{array}$ & Description & Source \\
\hline Biowearables & $\begin{array}{l}\text { Digital tattoos embedded with RFID technology that collects } \\
\text { biometric data and sends it to smartphone apps. Altered } \\
\text { behaviour. }\end{array}$ & Firger (2016) \\
\hline RFID & $\begin{array}{l}\text { Inserted subdermally (under the skin) and used as information } \\
\text { carrying devices for eg., opening doors, capturing biomet data } \\
\text { etc. Altered behaviour. }\end{array}$ & Eveleth (2016) \\
\hline Internal compasses & Inserted subdermally. Altered behaviour. & Monks (2014) \\
\hline $\begin{array}{l}\text { Implantable micro- } \\
\text { computers }\end{array}$ & Inserted subdermally, Altered behaviour. & Monks (2014) \\
\hline Internal headphones & Inserted subdermally. Altered behaviour. & Monks (2014) \\
\hline $\begin{array}{l}\text { Smart glasses (aka digital } \\
\text { eye glass, eye glass display, } \\
\text { personal imaging systems) } \\
\text { Smart contact lenses (e.g. } \\
\text { Sony device uses blinks to } \\
\text { record video) }\end{array}$ & $\begin{array}{l}\text { Wearable devices that display images to the visual field of a user. } \\
\text { Do not significantly distort vision for the wearer, an illusion of } \\
\text { coalescence between actual and virtual elements is achieved - } \\
\text { augmented reality. Technology includes processing capacity. } \\
\text { Display information and use of a sensor(s) to track, analyse, } \\
\text { distribute, and store data about the surrounding environment as } \\
\text { well as the user (e.g., accelerometers, magnetometers, GPS, } \\
\text { microphones, touchpads, eye-tracking cameras etc.). Designed } \\
\text { for continuous wearing by consumers: Google Glass, Recon Jet, } \\
\text { Microsoft HoloLens, or CastAR; for professionals e.g., } \\
\text { firefighting in reduced visual fields Epson Moverio series, Vuzix } \\
\text { M100, Kopin Golden-i, or ODG R7. Altered behaviour. }\end{array}$ & Hofman, et al. (2016) \\
\hline $\begin{array}{l}\text { Neuroprosthetics and } \\
\text { Human-brain interface } \\
\text { (brain-machine interface, } \\
\text { BMIs) }\end{array}$ & $\begin{array}{l}\text { Biological, mechanical, or biomechanical objects such as } \\
\text { surrogate bodies, vehicles, and other machines, controlled by } \\
\text { human nervous systems. Increasingly sophisticated and difficult } \\
\text { to discern from original body parts. Altered bio- and } \\
\text { physiological property. }\end{array}$ & $\begin{array}{l}\text { Hofman, et al. (2016) } \\
\text { Royal Society (2019) }\end{array}$ \\
\hline Cyborg tissue & $\begin{array}{l}\text { Nanobeing; Nanodevices that use tissue scaffolds with cell } \\
\text { cultures and measurement techniques to monitor tissue implants; } \\
\text { imperceptible in use. Altered biological property. }\end{array}$ & Zhang and Lieber (2016) \\
\hline $\begin{array}{l}\text { Neural enhancement and } \\
\text { psychoneural evolution }\end{array}$ & $\begin{array}{l}\text { Nootropic drugs - mind altering, expand intelligence, } \\
\text { imperceptible in use. Altered biological property. }\end{array}$ & Hofman, et al. (2016) \\
\hline Pseudogenetics & $\begin{array}{l}\text { Avatar definition data - may be spliced with other avatars data. } \\
\text { Collective intelligence. }\end{array}$ & Batchelar (2018) \\
\hline Microfluidic logic & $\begin{array}{l}\text { Fluid transports autonomously drive the catalytic decomposition } \\
\text { of a hydrogen peroxide fuel to produce water and oxygen gas and } \\
\text { the volume expansion that drives movement in a 'soft' robot. This } \\
\text { enables the 'bot' to produce mechanical movement without any } \\
\text { solid parts or external energy supply. Excess oxygen gas is } \\
\text { vented through microscopic pores. Altered physiological } \\
\text { behaviour. }\end{array}$ & Batchelar (2018) \\
\hline Self-directed evolution & $\begin{array}{l}\text { Postbiology; autoevolution. Genetic and biological level altered } \\
\text { behaviour. }\end{array}$ & $\begin{array}{l}\text { Lem, (1977) } \\
\text { Cirkovic, }(2017)\end{array}$ \\
\hline
\end{tabular}


Table 2: Potential transformation of FLE roles by cyborgs

\begin{tabular}{|l|l|l|}
\hline $\begin{array}{l}\text { Key Potential Cyborg } \\
\text { Attribute / } \\
\text { FLE Role }\end{array}$ & $\begin{array}{l}\text { Analytically-led transformation } \\
\begin{array}{l}\text { Melding of 'heavy duty' big data } \\
\text { analytics with an FLE cyborg's } \\
\text { tacit knowledge in real-time }\end{array}\end{array}$ & $\begin{array}{c}\text { Emotional Intelligence-led } \\
\text { transformation }\end{array}$ \\
$\begin{array}{l}\text { Melding of intuitive, emphatic, } \\
\text { analytical and mechanical } \\
\text { intelligences with technologies } \\
\text { such as facial coding }\end{array}$ \\
\hline Differentiator & $\begin{array}{l}\text { Leveraging customer specific data } \\
\text { to construct 'S60 degree profile of } \\
\text { customer' and communicate on the } \\
\text { spot 'wise decisions' based on this }\end{array}$ & $\begin{array}{l}\text { Ability to leverage dyadic } \\
\text { interaction style through adaptation } \\
\text { of emotional displays to optimise } \\
\text { appeal to customer and enhance } \\
\text { both episodic and relational } \\
\text { satisfaction }\end{array}$ \\
\hline $\begin{array}{l}\text { Coordinator and } \\
\text { Networker }\end{array}$ & $\begin{array}{l}\text { Ability to co-ordinate actors } \\
\text { (machine, cyborg and human) and } \\
\text { their interactions (H2H, H2M, } \\
\text { M2M, C2H, C2M, C2C)* within a } \\
\text { complex service eco-system }\end{array}$ & $\begin{array}{l}\text { Ability to identify interaction actor } \\
\text { as human, machine or cyborg and } \\
\text { leverage appropriate blend of } \\
\text { intelligence to ensure cohesion, } \\
\text { facilitation of network and } \\
\text { optimise customer service } \\
\text { experience }\end{array}$ \\
\hline Enabler & $\begin{array}{l}\text { Ability to audit customer skills, } \\
\text { competencies and experience in } \\
\text { real time to ascertain extent of } \\
\text { enabling required }\end{array}$ & $\begin{array}{l}\text { Ability to leverage rapport- } \\
\text { building to socialise and educate } \\
\text { customers to optimise co- } \\
\text { production resources }\end{array}$ \\
\hline Innovator & $\begin{array}{l}\text { Ability to fuse the auditing of } \\
\text { service eco-system with the } \\
\text { intuitive ability to 'read customers } \\
\text { minds' in real-time to identify } \\
\text { efficiencies and opportunities for } \\
\text { competitor differentiation }\end{array}$ & $\begin{array}{l}\text { Ability to leverage human } \\
\text { creativity and other intelligences to } \\
\text { generate creative and innovative } \\
\text { customer-focused service } \\
\text { improvements }\end{array}$ \\
\hline
\end{tabular}

*H2H (human-to-human), H2M (human-to-machine), M2M (machine-to-machine), C2H (cyborg-to-human), $\mathrm{C} 2 \mathrm{M}$ (cyborg-to-machine), C2C (cyborg-to-cyborg) 
Table 3: Cyborg FLEs: a research agenda

\begin{tabular}{|c|c|c|c|c|}
\hline \multirow[t]{2}{*}{ Res } & \multicolumn{4}{|c|}{ Examples of research questions (cross-cutting themes) } \\
\hline & Differentiator & Coordinator / Networker & Enabler & Innovator \\
\hline $\begin{array}{l}\text { Visibility- } \\
\text { invisibility of } \\
\text { technological } \\
\text { alteration }\end{array}$ & $\begin{array}{l}\text { What are acceptable } \\
\text { levels of (in)visibility of } \\
\text { technological alteration } \\
\text { and how is it signified for } \\
\text { differentiation to } \\
\text { stakeholders? } \\
\text { How does (in)visibility of } \\
\text { technological alteration } \\
\text { differentiate perceived } \\
\text { value of cyborg FLE } \\
\text { role? }\end{array}$ & $\begin{array}{l}\text { - What level of } \\
\text { (in)visibility of } \\
\text { alteration is necessary to } \\
\text { fulfil cyborg FLE role/s } \\
\text { of coordination and } \\
\text { networking? }\end{array}$ & $\begin{array}{l}\text { How relevant is the } \\
\text { 'uncanny valley' theory } \\
\text { in cyborg FLE contexts, } \\
\text { particularly where the } \\
\text { role is one of enabling } \\
\text { interactions and } \\
\text { relationships between } \\
\text { firms and customers? }\end{array}$ & $\begin{array}{l}\text { How does (in)visibility } \\
\text { influence perceived role } \\
\text { of cyborg FLE as } \\
\text { innovator? } \\
\text { If third parties are } \\
\text { involved in delivering } \\
\text { technological alteration, } \\
\text { how is ownership of } \\
\text { innovation managed } \\
\text { (who owns, etc.)? }\end{array}$ \\
\hline $\begin{array}{l}\text { Disclosure / } \\
\text { transparency of } \\
\text { technological } \\
\text { alteration to others }\end{array}$ & 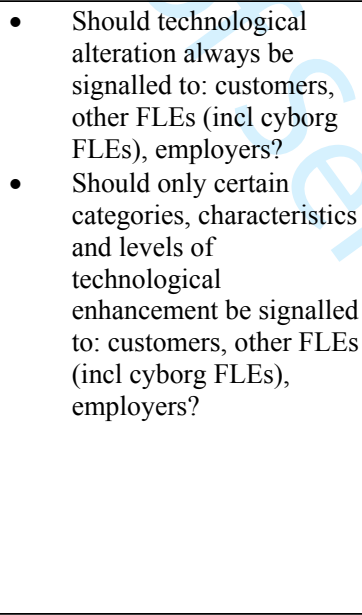 & $\begin{array}{l}\text { What types of } \\
\text { declaration clauses are } \\
\text { required in employment } \\
\text { contracts for cyborg } \\
\text { FLEs when data is } \\
\text { collected from } \\
\text { coordinator/networked } \\
\text { interactions? }\end{array}$ & $\begin{array}{l}\text { How is equality to be } \\
\text { extended for cyborg } \\
\text { FLEs as employees } \\
\text { when enabling becomes } \\
\text { fundamentally about } \\
\text { optimizing relationships } \\
\text { between firms and } \\
\text { customers? }\end{array}$ & $\begin{array}{l}\text { What categories, } \\
\text { characteristics and } \\
\text { levels of technological } \\
\text { enhancement become } \\
\text { sought after by service } \\
\text { firms - and how will the } \\
\text { differential advantage } \\
\text { generated be } \\
\text { incorporated into } \\
\text { innovation strategies? } \\
\text { How will firms manage } \\
\text { employees with } \\
\text { technological alterations } \\
\text { in roles where their } \\
\text { insight adds value } \\
\text { through innovation, } \\
\text { especially if the } \\
\text { alteration is supported } \\
\text { by third parties? }\end{array}$ \\
\hline $\begin{array}{l}\text { Customer } \\
\text { acceptance of } \\
\text { cyborgs as FLEs }\end{array}$ & $\begin{array}{l}\text { To what extent are } \\
\text { current models of } \\
\text { technology acceptance } \\
\text { relevant in the adoption } \\
\text { and deployment of } \\
\text { cyborg FLEs? } \\
\text { How are cyborg FLEs } \\
\text { perceived differently by } \\
\text { customers? }\end{array}$ & $\begin{array}{l}\text { As coordinators/ } \\
\text { networkers, to what } \\
\text { extent are current } \\
\text { models of interpersonal } \\
\text { trust relevant for } \\
\text { relationship } \\
\text { development and } \\
\text { management for cyborg } \\
\text { FLEs? }\end{array}$ & $\begin{array}{l}\text { Is trust defacto } \\
\text { irrelevant in contexts of } \\
\text { 'perfect' information } \\
\text { between cyborg FLEs } \\
\text { and customers (where } \\
\text { the cyborg FLE is able } \\
\text { to read the mind and } \\
\text { behaviour of the } \\
\text { customer)? }\end{array}$ & $\begin{array}{l}\text { How should } \\
\text { superintelligence of } \\
\text { cyborg FLEs be } \\
\text { managed for innovation } \\
\text { in service contexts? }\end{array}$ \\
\hline $\begin{array}{l}\text { Cyborg FLE- } \\
\text { customer power } \\
\text { balances }\end{array}$ & $\begin{array}{l}\text { How should competitive } \\
\text { advantage over non- or } \\
\text { less- technologically } \\
\text { altered others to be } \\
\text { managed? }\end{array}$ & $\begin{array}{l}\text { What are acceptable } \\
\text { levels of power } \\
\text { imbalance and } \\
\text { circumstances of its use } \\
\text { where the cyborg FLE is } \\
\text { technologically } \\
\text { advanced? (by firm, say } \\
\text { depending on criticality } \\
\text { of interaction } \\
\text { determined by socio- } \\
\text { cultural preferences e.g., } \\
\text { doctor, politician versus } \\
\text { customer service } \\
\text { provider) }\end{array}$ & $\begin{array}{l}\text { What are acceptable } \\
\text { levels of cyborg FLE } \\
\text { influence as enabler in } \\
\text { relationships with } \\
\text { customers when } \\
\text { technological alterations } \\
\text { are leveraged? }\end{array}$ & $\begin{array}{l}\text { What is the boundary } \\
\text { between acceptable } \\
\text { influencing and } \\
\text { manipulation when } \\
\text { cyborg FLEs are service } \\
\text { intermediaries resulting } \\
\text { in innovations? }\end{array}$ \\
\hline $\begin{array}{l}\text { Privacy and } \\
\text { Security related to } \\
\text { cyborg FLEs }\end{array}$ & $\begin{array}{l}\text { How is data acquired and } \\
\text { managed by the cyborg } \\
\text { FLE through sensing then } \\
\text { managed by the firm? } \\
\text { What are appropriate } \\
\text { ethical issues in relation } \\
\text { to privacy and security } \\
\text { under conditions of } \\
\text { acquisition through } \\
\text { technological alteration? }\end{array}$ & $\begin{array}{l}\text { How is privacy and } \\
\text { security of data } \\
\text { maintained; lifecycle of } \\
\text { data managed/protected/ } \\
\text { updated to reflect } \\
\text { current business } \\
\text { practices or cyborg FLE } \\
\text { status changes within } \\
\text { the firm? }\end{array}$ & $\begin{array}{l}\text { How is data ported to } \\
\text { new cyborg FLE actors, } \\
\text { or transferred when } \\
\text { cyborg FLEs provide } \\
\text { services to competitor } \\
\text { firms, or they simply } \\
\text { change jobs? }\end{array}$ & $\begin{array}{l}\text { In a data economy, how } \\
\text { will embodied } \\
\text { knowledge that is tacit, } \\
\text { implicit and explicit and } \\
\text { is differentiated by } \\
\text { enhanced senses, lead to } \\
\text { new insights and } \\
\text { provide new types of } \\
\text { data for exploitation by } \\
\text { the firm? }\end{array}$ \\
\hline
\end{tabular}


